\title{
The Influences of Metacognitive Awareness on Reading Comprehension in Iranian English Undergraduate students in Kerman, Iran
}

\author{
Leila Anjomshoaa (Corresponding author) \\ Department of Modern Language \\ Islamic Azad University, Kerman Branch, Iran \\ Tel: 0098-0341-320-1922Ｅ-mail: Leila.anjomshoa@gmail.com \\ Samira Golestan \\ Department of Social Science \\ Islamic Azad University, Kerman Branch, Iran \\ Tel: 0098-913-343-6185_E-mail: Samira_golestan@yahoo.com \\ Ali Anjomshoaa \\ Department of Modern Language \\ Islamic Azad University, Kerman Branch, Iran \\ Tel: 0098-914-016-0107_E-mail: Ali.anjomshoa@yahoo.com
}

Received: 11-07- 2012

doi:10.7575/ijalel.v.1n.6p.193
Accepted: 16-08- 2012

Published: 01-11- 2012

\begin{abstract}
Reading is a very complex process, and readers need to actively engage the text to understand the intended message of the author. Readers, by employing the appropriate reading strategies, can understand texts more efficiently and not waste too much time and energy to comprehend the given text. The aim of this research is to examine the role of metacognitive awareness on reading comprehension among students in English undergraduate studies at Azad University of Kerman, a province in Iran. Data were collected by questionnaire from 81 Iranian EFL undergraduate students of English. The results of Pearson Correlation analyses showed a significant moderate positive relationship between metacognitive awareness and reading comprehension $(\mathrm{r}=$ $-0.416, p<.01)$ where students who asserted using effective reading strategies also appeared to achieve higher reading abilities. Results confirm that being aware of reading metacognitive strategy considerably affects reading comprehension. The findings suggest that the students who are aware of a range of efficient reading strategies can significantly enhance their reading ability. The final conclusions of the paper include a discussion about pedagogical implications of the results.
\end{abstract}

Keywords: Reading comprehension, Metacognitive strategies, Undergraduate Students

\section{Introduction}

English as an international language is used throughout the world for different purposes such as communicating with other people from different countries and providing a means for exchanging knowledge (Mehrpour, Razmjoo, \& Kian, 2011). Reading tends to be a highly valued second language skill, particularly in higher educational levels at English-based universities, and it plays a paramount role in programs that extensively employ English written materials. It is clear that students need acceptable reading skills in English as their second language to succeed in their university education (Zare, 2007) as well as expand their knowledge of the language, culture, and international perspectives (Yang, 2010).

In recent decades, there has been sustained interest in promoting reading as a significant means of language development for foreign language learners (Susser \& Robb, 1990). Reading as one of the four language skills including (listening, writing, reading and speaking) is necessary for second language learners to proceed as skillful users of the target language. Reading ability is perceived as the most stable and durable skill among the second language ones (Maher Salah, 2008; Rivers, 1981). 
The ultimate aim of a second language learner is to comprehend the meaning of the given text like native speaker readers. Traditionally reading was regarded as a receptive skill in which the readers were seen as passive recipients, but, in fact, reading is an interaction between the text and the reader. "The reader interacts with the text to create meaning as the reader's mental processes interact with each other at different levels (e.g. letter, lexical, syntactic, or semantic) to make the text meaningful" (Barnett, 1989, p. 29). While reading, the reader is involved in the active and productive process of constructing meaning from a given passage (Haas \& Flower, 1988).

In the domain of both first and second language reading research, recent trends have led to an increasing emphasis on the role of metacognitive awareness of one's cognitive and motivational processes in reading (Alexander \& Jetton, 2000; Pressley, 2000, Gou, 2008; Pressley, 2000). Indeed, many researchers have agreed that awareness and monitoring of one's comprehension processes are critically important in predicting reading comprehension. Similarly in the L2 research, many researchers have established the role of metacognitive awareness in reading comprehension (Barnett, 1989; Carrell \& Floyd, 1987; Chamot, 2005; Gou, 2008).

Metacognitive knowledge refers to "knowledge about knowledge" or "thinking about thinking" (Alexander, Schallert \& Hare 1991, p.328). According to Auerbach and Paxton (1997), metacognitive awareness is defined as the process of understanding the necessary strategies to process a text, being able to comprehend it and apply appropriate strategies as necessary. An important reading skill, known as comprehension monitoring, is the ability to perceive that the true understanding has not been achieved (Anderson, 1999; Hassin, 2008) and apply adjusted reading strategies to remedy the situation. Metacognitive knowledge, which can be acquired in a formal or deliberate way or informally or incidentally, helps learners become conscious of what they understand and enables them to express this knowledge more easily (Wenden 1998).

Not only is Metacognitive knowledge an awareness of strategies, but it is also about being aware of themselves as learners through the tasks they face, and the strategies they choose (Baker \& Brown, 1984; Wang, 2009). Application of metacognitive theory in language learning depends on the strategy that someone uses to plan, organize, evaluate, and monitor his or her process of language learning (O'Malley \& Chamot, 1990; Wang, 2009). After application of metacognitive studies in the L1 context, second language researchers have also been attracted to employ metacognitive strategies in second language learning process, especially in reading skills (Wang, 2009).

Whether in L1 or L2, reading is considered a cognitive enterprise that entails three components including reader, text and activity (Flavell, 1979; Gou, 2008; Snow \& Sweet, 2003). Thus, readers must utilize metacognitive awareness and invoke the conscious use of reading strategies in order to comprehend the text successfully. Chamot (2005) suggests that it is important for language teachers to help EFL students develop their metacognition in language classrooms because metacognition helps them choose the most appropriate strategies according to a given task and their individual language learning preferences. Teaching English as a foreign language is quite widespread in Iran. Most of the Iranian learners are university students who need to read specialized books related to their fields of study. Since most of their sources are in English, language learners are very much interested in developing their reading skills. Despite positive findings about metacognitive strategies in reading instruction in the US context, many English teachers in Middle-eastern countries, such as Iran, still follow the traditional method of grammar translation that makes students memorize vocabulary and grammatical structures (Huang, 2006; Merkelnach, 2006; Phakiti, 2003; Song, 1998; Wang, 2009).

Also, there are few studies carried out on the relationship between metacognitive awareness and reading comprehension among Iranian students. For example: Mahmoudi, (2010) examined the relationship between the degree of metacognitive awareness of reading strategies and comprehension monitoring among students EFL learner in Mazandaran (a city in Iran). The results suggested that metacognitive awareness can affect language learners' monitoring behavior during reading comprehension. Thus, there is a need to research in this field. So, this research attempts to examine the relationship between metacognitive awareness and reading comprehension of Iranian EFL undergraduate students of English Studies in Islamic Azad University of Kerman.

\section{Literature review}

Reportedly there is a positive correlation between proficient second language reading and awareness of applying appropriate reading strategies in English reading tasks (Barnett, 1989; Kern, 1989). Several researchers have pointed out that metacognitive awareness or metacognition must be employed appropriately to choose effective reading strategies during the reading process (Carrell, Gajdusek, \& Wise, 1998; Cordero-Ponce, 2000; Sheorey \& Mokhtari, 2001). Various studies have revealed that reading ability can be increasingly improved if students 
take advantage of metacognitive processes; it happens when students become aware of monitoring and assume control of their own reading (Baird, 1998; Hacker, 1998; White \& Gunstone, 1989).

With regard to the relationship between metacognitive awareness and reading comprehension in Asian learners, Wang (2009) studied 110 EFL students in Taiwan and found strong correlations between metacognitive awareness and reading comprehension. Similarity, Gou (2008) examined the relationship between metacognitive awareness of reading strategies and reading comprehension among 278 Chinese college students. The results showed that there is significant relationship between metacognitive awareness and reading comprehension. In a European context, Gelderen et al. (2003) used a questionnaire to measure metacognitive awareness and a multiple-choice English Reading Test to measure reading comprehension with 397 Dutch students and found a significant positive correlation of 0.72 .

Takallou (2005) examined the effect of metacognitive awareness on EFL learners' reading comprehension among 94 male and female students in Kermanshah, Iran. The collected data from two experimental groups in the reading comprehension test showed that those who received instruction that included 'planning' and 'self-monitoring' had a better performance than the control group. Moreover, data analysis revealed that after giving instruction about metacognitive strategies awareness, the experimental group's performance improved considerably. In addition, Rahman et al., (2010) investigated the impact of metacognitive awareness on students' performance among 900 students in Pakistan. As their results showed, metacognitive awareness has an appreciable correlation with the performance of students. The students who had metacognitive awareness were more likely to do better on the test.

Furthermore, after studying the relationship between applied cognitive and metacognitive strategy in an EFL reading comprehension test among 384 undergraduate students between the ages of 17 and 21 at Thai University, Phakiti (2003) realized that application of cognitive and metacognitive strategies had a positive relationship with reading test performance; also, highly successful performers on the reading test explained that they extensively employ higher metacognitive strategies than their moderately successful peers. The data collected from the unsuccessful group revealed that they apply this strategy much less frequently than the two other successful groups. In another study by Phakiti and Coutinho (2006) among 358 undergraduate students in a university in Thailand, concluded that students with good metacognition can be successful readers but students with poor metacognition tend to perform poorly.

\section{Methodology}

This correlational study investigates the pattern of relationships between Metacognitive awareness and reading comprehension. The method of data collection was questionnaire. The total number of EFL students from the English Department in undergraduate level at Azad University of Kerman was 450 students. A sample of 81 students in undergraduate level between the ages 19 and 21 years from the English Department that was determined based on the G Power, were participated in the study. These samples were randomly selected.

\subsection{Instruments}

The data collection instruments used in this study were as follows:

\subsubsection{Reading Comprehension Measures}

TOEFL Reading Comprehension Subtest (TOEFL-RBC) is a standardized multiple-choice reading comprehension test (Schedl, Thomas \& Way, 1995). Participants attending the test must read five passages that express general academic subjects and answer 30 multiple-choice questions for each passage. Qian and Mary (2004) reported that internal reliability of the test was .90 for adults with various native language backgrounds. Developers of the instrument do not mention any thing about the nationality of their participants. The internal consistency reliability of this measure was .85 for the sample of this study.

\subsubsection{Metacognitive Reading Strategies Questionnaire (MRSQ)}

Metacognitive Reading Strategies Questionnaire: This 22-item questionnaire was developed by Taraban, Kerr and Ryneason (2004) to determine the extent of awareness among college students in reading strategies during the reading process. It asks test takers to choose how frequently they apply the listed strategies on a five-point Likert scale; the choices are 1. Never Use 2. Rarely Use 3. Sometimes Use 4. Often Use 5. Always Use. Cronbach's alpha coefficient for the current sample who used this instrument was 0.80 for all items.

\subsection{Data analysis}




\section{International Journal of Applied Linguistics \& English Literature \\ ISSN 2200-3592 (Print), ISSN 2200-3452 (Online)}

Vol. 1 No. 6; November 2012

The SPSS program version 16 was used to conduct the analysis of the data. Two statistical procedures of descriptive and inferential statistics were used. The inferential statistics utilized in this study was Pearson Correlation Analyses. Two-tailed product-moment correlations were computed for scores from the reading comprehension, and metacogntive awareness to find any possible relationship between the two variables.

\section{Results and Discussion}

\subsection{Descriptive Statistics results of Participants' Performance on the Instruments}

Table 1 presents the descriptive statistics results of the participants' performance on the instruments, including the summary of mean, standard deviations, and variance value of each variable examined in the study.

Table 1: Descriptive Statistics of Key Variables

\begin{tabular}{lcccc}
\hline & $\mathrm{N}$ & Mean & Std. Deviation & Variance \\
\hline $\begin{array}{l}\text { Metacognitive } \\
\text { awareness }\end{array}$ & 81 & 26.222 & 10.9886 & 120.750 \\
\hline $\begin{array}{l}\text { Reading } \\
\text { Comprehension }\end{array}$ & 81 & 27.234 & 10.6516 & 113.457 \\
\hline $\begin{array}{l}\text { Valid N } \\
\text { (Listwise) }\end{array}$ & 81 & & & \\
\hline
\end{tabular}

As the table shows, 81 students were examined in this study, and the mean scores of metacognitive awareness and reading comprehension are 26.22 , and 27.23 , respectively.

\subsection{Relationship between Metacognitive Awareness and Reading Comprehension}

In order to determine the relationship between the Metacognitive Awareness and Reading Comprehension, the Pearson Correlation Analyses, were performed. The results obtained from these computations are presented in the following matrix of correlations.

Table 2: Pearson Correlation Test between Metacognitive awareness and reading comprehension

\begin{tabular}{lll}
\hline & & Metacognitive awareness \\
\hline $\begin{array}{l}\text { Reading } \\
\text { comprehension }\end{array}$ & Pearson Correlation & $.416^{* *}$ \\
\hline & Sig. & .000 \\
& $(2$-tailed) & \\
\hline & $\mathrm{N}$ & 81 \\
\hline \multirow{2}{**}{. Correlation is significant at the .01 level (2-tailed). }
\end{tabular}

As depicted in Table 2, there was a moderate relationship ( $\mathrm{r}=.416)$ between metacognitive awareness and reading comprehension based on Guilford's (1950) rule of thumb. The results also indicated that this relationship was significant and positive $(\mathrm{r}=.416, \mathrm{p}<0.01)$. It can be concluded that there is a significant relationship between metacognitive awareness and reading comprehension.

This supports the findings of studies carried out by Gelderen et al., ( 2003), Takalloy (2005), Zaree (2007), Hassin (2008) and Gou (2008) who found that there is a significant correlation between metacognitive awareness and reading comprehension among EFL and ESL readers, where students who asserted they used efficient reading strategies also proved to have higher reading ability. As the literature shows, metacognitive awareness significantly contributes to reading comprehension in L2. This suggests that teaching language learners about 
International Journal of Applied Linguistics \& English Literature

ISSN 2200-3592 (Print), ISSN 2200-3452 (Online)

Vol. 1 No. 6; November 2012

different kinds of applicable strategies, they will be able to select the appropriate strategies that facilitate getting meaning from the prepared text.

\section{Conclusion}

As discussed previously, the core interest of this study was to examine whether there was a relationship between metacognitive awareness and reading comprehension among students studying English at Azad University in Kerman. The results showed, there was a significant relationship between metacognitive and reading comprehension $(\mathrm{r}=.416 ; \mathrm{p}<.01)$. The findings were consistent with the findings of the previous research.

The results reinforce the conclusions of reading comprehension analysis on language learning techniques and strategies which imply that employment of specific strategies may affect constructively on reading comprehension of learners. English instructors who work in Iran should be aware of the necessity of applying integrated reading instruction strategies into regular English classes to improve their learners' reading comprehension ability. As researchers have emphasized, strategies like think-aloud, pair work or pair share can help English language learners and can make the text seem more reasonable and understandable while reading (Douglas, 2005; Hassin, 2008; Kymes, 2005). More research can be done by using an experimental design in with the effect of think-aloud and pair work on enhancing students' achievement in reading comprehension can be investigated.

\section{References}

Alexander, A., Schallert, L., \& Hare, V. (1991). Coming to Terms: How Researchers in Learning and Literacy Talk About Knowledge. Review of Educational Research, 61(3), 315-343.

Alexander, P., \& Jetton, T. (2000). Learning from text: a multidimensional and developmental perspective (In: Kamil, M., Mosenthal, P., Pearson, P.D., Barr, R. (Eds) ed.). Lawrence Erlbaum, Mahwah: NJ, pp.

Anderson, N. (1999). Exploring second language reading. Canada.: Heinle \& Heinle.

Baker, L., \& Brown, A. (1984). Mrtacognitive skills and reading ( In P.D. Pearson, R. Barr. M.L. Kamil, \& P. Modrnthal, (Eds.) ed.). New York: Longman.

Barnett, M. (1989). More than Meets the Eye: Foreign Language Reading: Theory and Practice. Englewood Cliffs: New Jersey: Prentice Hall Regents.

Carrell, P., \& Floyd, P. (1987). Effects on ESL reading of teaching cultural content schemata. Language Learning, 37, 89 - 108.

Carrell, P., Gajdusek, L., \& Wise, T. (1998). Metacognition and EFL/ESL reading. Instructional Science(26), 97-112.

Chamot, A. (2005). Language learning strategy instruction: Current issues and research. Annual Review of Applied Linguistics, 25, 112-130.

Cordero-Ponce, W. (2000). Summarization instruction on foreign language comprehension. Reading Research and Instruction, 39 (4), 329-350.

Douglas, E. (2005). Reading comprehension strategies for English language learners, from http://www.learnnc.org/lp/pages/724

Flavell, J. (1979). Metacognition and cognitive monitoring: A new era of cognitive-development inquiry. American Psychologist, 34, 906-911.

Gou, Y. (2008). THE Role of Vocabulary Knowledge, Syntastic Awareness and Metacognitive Awareness in Reading Comprehension of Adult English Language Learners University of Florida.

Guilford, J. (1950). Fundamental statistics in psychology and education (2th ed.). New York: McGraw-Hill.

Haas, C., \& Flower, L. (1988). Rhetorical Reading Strategies and the Construction of Meaning. College Composition and Communication, 39(2), 167-183.

Hassin, F. (2008). METACOGNITIVE STRATEGY AWARENESS AND READING COMPREHENSION. Journal of English Language Teaching and Learning, 22(3), 44-49.

Huang, J. (2006). Learner resistance in metacognition training? An exploration of mismatches between the learner and teacher agendas. Language Teaching Research, 10(1), 95-117. 


\section{International Journal of Applied Linguistics \& English Literature \\ ISSN 2200-3592 (Print), ISSN 2200-3452 (Online) \\ Vol. 1 No. 6; November 2012}

Kern, R. (1989). Second language reading strategy instruction: its effects on comprehension and word inference ability. Modern Language Journal, 73, 135-149.

Kymes, A. (2005). Teaching online comprehension strategies using think-alouds. Journal of Adolescent \&Adult Litracy, 48, 492-500.

Maher Salah, S. (2008). THE Relationship between Vocabulary Knoeledge and Reading Comprehension of Authentic Arabic Texts Brigham Young University.

Mehrpour, S., Razmjoo, S., \& Kian, P. (2011). The Relationship between Depth and Breadth of Vocabulary Knowledge and Reading Comprehension among Iranian EFL Learners. Journal of English Language Teaching and Learning, 222(53).

Merkelnach, C. (2006). The Negative Influence of ESL-Methodology on the acquisition of an L3 in Taiwan.

O'Malley, M., \& Chamot, A. (1990). Learning strategies in second language acquisition. New York: Cambridge University Press.

Phakiti, A. (2003). A closer look at gender and strategy use in L2 reading. Language Learning, 53, 649- 702.

Rivers, W. (1981). Teaching Foreign Language Skills (2nd ed ed.). Chicago: University of Chicago Press.

Sheorey, R., \& Mokhtari, K. (2001). Differences in the metacognitive awareness of reading strategies among native and non-native readers. System, 29, 431-449.

Snow, C., \& Sweet, A. (2003). Reading for comprehension ( In A.P. Sweet \& C.E. Snow (Eds.) ed.). New York: Guilford Press.

Song, M. (1998). Teaching reading strategies in an ongoing EFL university reading classroom. Asian Journal of English Language Teaching, 8, 41-54.

Susser, B., \& Robb, T. (1990). Extensive Reading Instruction: Research and Procedure. JALT Journal, 12, $161-185$

Wang, M. (2009). Effects of Metacognitive Reading Strategy Instruction on EFL High Students' Reading Comprehension, Reading Strategies Awareness, and Reading Motivation. University of Florida.

Wenden, A. (1998). Metacognitive Knowledge and Language Learning. Applied Linguistics, 19 (4), 515-537.

Yang, Z. (2010). An Investigation of Cognitive Learning Styles and Strategy Use in EFL Reading Comprehension among University Student. I-Shou Unversity.

Zare, A. (2007). The Relationship between Cognitive and Meta-cognitive Strategy use and EFL Reading Achievement. Journal of Applied Psychology, 2(5). 